\title{
CHAPTER
}

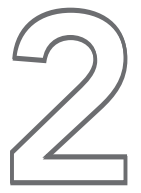

\section{What Is Racism?}

\section{INTRODUCTION}

In a class on racism in a graduate school for social workers, students are asked to define themselves racially and ethnically. A White male student from a predominantly White suburb in the midwestern United States responds: "I think of myself as an American. I treat everyone the same, and don't like to see race. I don't care if you're Black, Brown, red, orange, or purple. People are people!"

An African American woman from Los Angeles responds: "I'm Black, African American, part Cherokee Indian. All of my life I've been defined by my race. I'm proud of who I am. When you say you don't see race, you don't see me. It's as if you're telling me to be White, which is racist."

The first student responds, somewhat defensively: "This is what I hate about all of this focus on race and racism. People misjudge me and distort what I say, and before I know it, I'm called a 'racist."'

A White Jewish woman from Boston adds: "I'm not White, I'm Jewish. I have never felt 'White."'

A Chicana woman from South Texas responds passionately: "You're a racist! All White people are racists, because you don't even know that you have a race and that your race gives you thousands of privileges I never get!"

The class attendees shift in their seats, and an uneasy silence descends on the class.

This vignette is similar to discussions that have taken place in many, if not most classes about racism that we have taught. It illustrates the difficulty in talking about race and racism, and also reveals the lack of clarity about race and racism and the different perspectives about the salience of these concepts for people today. The conversation also raises questions about the similarities and differences between race and ethnicity and the experiences of people of color and White people, including those who view themselves as neither White nor people of color. Lastly, it illustrates the particular difficulties for White people to engage in a meaningful conversation about race and racism because of fears of being called a racist or being seen as a morally compromised or flawed person (DiAngelo, 2018).

Sources of the tension and confusion are complex and very real for the participants. We also could have added that some people in the class consider themselves to be biracial, 
multiracial, or multiethnic. They might think that the discussion was encouraging them to define themselves narrowly and in binary terms, and that they were being pressured to make choices that privileged one aspect of their identity while denying, even sacrificing, another. Others might say that neither race nor ethnicity is important to them; they are more concerned with their gender or sexual orientation. Some might think the discussion about race is misguided, as inequality and oppression are really about social and economic class.

What is racism? Is it feeling and thinking with prejudice and bias, or is it something much bigger? If a person treats everyone the same, are they not a racist? Or are all people from a social category racist? Can only White people be racists, or can anyone be a racist? Is racism active, or can it also be passive? We respond to these questions in this chapter.

\section{HOW RACE AND RACISM HAVE BEEN CONCEPTUALIZED}

In 1999, the American Anthropological Association (AAA, 1998) published a statement about race that its executive board had adopted previously. The board explained that the statement did not have a consensus but that it was representative of current scholarly thinking by anthropologists about race. The conclusion was that race is not a legitimate biological or genetic construct; rather, it is an ideology used to justify the domination of one identifiable group of people by another - a rationale that has supported many forms of oppression, including genocide, slavery, ethnic cleansing, colonialism, and other forms of domination, mistreatment, and resource and opportunity hoarding.

Throughout history, groups of people have been marginalized, targeted, attacked, enslaved when they are socially constructed as being different and "inferior," based on religion, ethnicity, culture, skin color, phenotype as well as "race" (Painter, 2010). In the United States, however, racism has usually been based on assumptions of biological differences, which could supposedly be identified by skin color, which is a factor of a single gene mutation 8,000 years ago and tells us nothing else about a person (Kolbert, 2018). "Scientific racism" offered a veneer of science confirming the innate superiority or inferiority of "racial" groups, assuming distinct races: Caucasian, Negroid, and Mongoloid. Even though these terms are rarely used today, the assumptions about discrete racial groups lingers. For example, the census continues to classify people by race. Yet the AAA stated:

Human populations are not unambiguous, clearly demarcated, biologically distinct groups. Evidence from the analysis of genetics (e.g., DNA) indicates that there is greater variation within racial groups than between them .... Throughout history whenever different groups have come into contact, they have interbred. The continued sharing of genetic material has maintained all of humankind as a single species. (AAA, 1998, p. 712)

All human beings evolved from Africa and there is more genetic diversity within groups living in Africa than on all other continents combined (Kolbert, 2018). Thinking of all of humankind as a single species certainly is not how race has been conceptualized, particularly in the Western world. And it certainly does not mesh with how "racial" groups have been treated historically in the United States and many other parts of the world today. 
So, how did the notion of distinct races occur, and why did this conceptualization lead to a legacy of racism? This huge question has occupied many historians, anthropologists, sociologists, and psychologists, as well as politicians and a range of citizens. It is such a complex question that it may never be answered completely, and certainly will always be contested. Further, it is not as if anyone who is studying or writing about this subject has a completely "objective" vantage point, because in a racialized society and world, everyone is racially situated. Therefore, all those who write about race and racism must recognize and share their assumptions, values, and biases.

In this chapter, we explain some of the more prevalent theories about race and racism and how these came to be, and then describe the concepts and terms used in this book. Our position, which follows, is that race is a social construction-categories such as "White" are fungible, unstable, and in many ways arbitrary but racism is a very real, multifaceted, historical, and contemporary sociopolitical force. We also believe strongly that ending racism is a moral, ethical, political, and social imperative for all citizens, but particularly helping professionals. We have been guided in our research, work, and teaching by a body of scholarship by a range of theoretical orientations, particularly critical race theory and critical realism, which we describe as well.

\section{Historical Underpinnings}

Throughout history, there has been intergroup conflicts, resulting in enslavement, massacres, and genocide (Kiernan, 2009; Power, 2002). But in order for this dynamic to be a form of racism, there needs to be a concept of race. The historian George Fredrickson, who has spent his career writing about race and racism, traced how racism was linked initially with religious intolerance in Europe (Fredrickson, 2002). Unlike religious bigotry, however, which always held the potential for people to be accepted if they were to change their faith, racism relies on an essentialist, fixed, unchanging view of human beings.

Fredrickson writes that some of the first stirrings of modern racism were in the Iberian Peninsula in the 15th and 16th centuries. During that time, the Spanish, while battling the Moors, conceptualized Jews as having "impure" blood. Along with the Portuguese, the Spanish were beginning to explore Africa and the Americas (Diamond, 1997). This led to Europeans having much more contact with Native American Indians in North America, eventually enslaving and killing them, and with Africans in Africa who were systematically enslaved and shipped to North America. Eventually race became a "scientific" term, and White Europeans would consistently group "races," with Whites at the top of an alleged racial hierarchy (Kolbert, 2018).

In turn, this served as an economic underpinning for European colonization of the Americas, and later Africa and other parts of the world. This condition created a racially oppressive social structure, requiring a legitimizing rationale. The structure of European colonialism endures throughout the world: Former colonial powers are almost always wealthier than their former colonies, often continuing the process of extraction of their natural resources. And the racial hierarchies structured by colonialism continue. For example, domestic servants in Western countries are often people of color from former colonial nations while the reverse is rarely true. Colonialism was the foundation of White supremacy: a system of sociopolitical domination, formal and informal, that led to the subjugation of people from an alleged different race (Yancy \& Mills, 2014). While formal European colonialism ended in the mid to late 
20th century, White supremacy endures both structurally and as a cognitive and social framework recognized as coloniality, although it is never explicitly named as such; it is so normal for many White people that it is rendered invisible to them.

\section{The Western Concept of Race}

The modern Western concept of race had its roots in colonialism's seismic historical dislocations and collisions but received a conceptual frame, buttressing the exploitation of distinct groups of people, from the European Enlightenment. The Enlightenment viewed human beings as having descended from animals rather than as being children of God (Fredrickson, 2002). It also was a time of classification, of "scientifically" ordering the world, as well as establishing and privileging Western cultural and aesthetic norms.

All of this led to categorizing people into races, as well as favoring the White (or Caucasian) race as being the most intelligent and having the highest standards of beauty, culture, and conduct. As Fredrickson has pointed out, this coalescing of European thinking about race had the ironic effect of serving as a foundation for the biological determinism and scientific Darwinism of the 19th century while also articulating ideals of equality and justice, which would be used later to question and undermine the rationale for racism.

Certain groups of people do have clear physical differences-such as skin tone, hair color and texture, and facial features. Nevertheless, the genetic evidence cited by the AAA and others is that there is far greater genetic variation within "racial" groups than between them. Genetic researchers estimate that $88 \%$ to $90 \%$ of genetic variation occurs within local populations, whereas only $10 \%$ to $12 \%$ is between populations (Angier, 2000). Much of the perceived variation between races resulted from migration and adaptations to increase survival in a specific region, such as having darker skin in sunnier areas (Angier, 2000; Kolbert, 2018).

Although the conclusions of geneticists and other scientists are not unanimous, the consensus is that all human beings descended from the same original ancestors and that we are all, ultimately, of the same race (Angier, 2000; Kolbert, 2018). Lopez (1994) concluded that "the idea that there exist three races, and that these races are 'Caucasoid,' 'Negroid,' and 'Mongoloid' is rooted in the European imagination of the Middle Ages" (p. 13).

Perhaps during some periods of human existence, there was little commingling of distinct human groups, but this has not been the case for thousands of years. In the United States, all "races" have coexisted and interbred for centuries. Or, as Cartmill (1999) stated: "If races are defined as geographically delimited conspecific populations characterized by distinctive regional phenotypes, then human races do not exist now and have not existed for centuries" (p. 651).

Yet, the concept of race, both scientific and cultural, has been used ever since the inception of the United States to justify severe exploitation and terrible economic and social inequalities. Dehumanization and racial denigration served to rationalize the enslavement, murder, and slaughter of American Indians; enslavement and torture of African Americans; dispossession, massacres, ethnic cleansing, and loss of rights of Mexican Americans; exclusion of Chinese and Japanese immigrants; and pogroms against many of these groups (Dunbar-Ortiz, 2015; Resendez, 2017; Takaki, 1993). The wedding of racial essentialism, White supremacy, and social Darwinism led to further justifications for social and economic exclusion, as well as to pathologizing the cultures and mental health of groups considered to be "inferior" (Jansson, 2015; Rollock \& Gordon, 2000; Steinberg, 2001). 
Sadly, social Darwinist tracts, although widely discredited, still survive in our modern era. An example is Hernstein and Murray's (1994) book, The Bell Curve: Intelligence and Class Structure in American Life, which explains social inequality by virtue of genetic differences in intelligence (Taylor, 1997). This echoes and articulates a common discourse-it is character, lack of intelligence, or cultural shortcomings that are the source of differential progress between groups socially constructed as being racially different-while ignoring or downplaying the structural systems of racialized barriers and privilege that persist to this day. Thus, the concept of race does not exist or make sense without considering the dynamics of racism. We now consider some principal theories about the nature of racism and its relationship to the construct of race.

\section{THEORIES ABOUT RACISM}

A multitude of theories conceptualize racism and race (see Exercise 2.1). For the sake of organizational simplicity, we group them here into the following meta-categories: ethnicity theories, race relations theories, psychological theories (including theories of prejudice and disease theories), and structural theories (including postcolonial, Marxist, and opportunity theories). We then discuss in greater detail critical race theory and critical realism, which are central theoretical frameworks for this book.

One of the conceptual fault lines that runs through most of the literature about racism and race, and which seems to defy theoretical categories, is whether the problem is conceived of in binary or multiracial terms. Scholars advocating the binary concept often examine racism as a Black/White problem, using concepts and data that separate race and racism into these two categories. Multiracialists view race and racism as being part of a larger prism, with many racial and ethnic groups, and a meaning of race that is continually shifting, fluid, contested, and contextual (Omi \& Winant, 2014).

\section{Ethnicity Theories}

What unites ethnicity theorists is their belief that racism should be seen as a form of ethnocentrism, which can occur in any ethnic group and can lead to conflict or oppression with any other ethnic group. Race is viewed as only one facet of a group's ethnic identity (Omi \& Winant, 2014). This theory also emphasizes a group's immigration experience, how rapidly or slowly members of this group assimilate and acculturate into mainstream U.S. society, the cultural capital they carry and have generated, and how well this assists the group in moving forward socially and economically. In keeping with this theory, Chinese Americans, African Americans, Latino Americans, and American Indians are viewed as ethnic groups, as are Jewish Americans, Italian Americans, and Irish Americans, all with their unique histories of oppression, adaptation, survival, and success.

Some of the key scholars within this prototype are Glazer and Moynihan (1963), who coauthored Beyond the Melting Pot); Gordon (1964); and Myrdal (1962). One of the achievements of this movement was to shift the predominant racial discourse away from biological determinism to a consideration of cultural pluralism and assimilation (Omi \& Winant, 2014). This theory does not place a great deal of emphasis on power and opportunity; rather, the focus is on cultural differences and the degree of fit with Anglo-American culture (Feagin \& Feagin, 1994). 


\section{Racism in the United States}

Ethnicity theories fit well with a liberal conception of democracy, in which everyone should be afforded equal rights and opportunities. Thus, ethnicity theorists supported the civil rights movements of the 1950s and 1960s, concerned that ethnic groups such as African Americans were being denied full participation in American society, including the capacity to assimilate. They advocated removing legal and institutional barriers and were for equal opportunity (Omi \& Winant, 2014).

The ethnicity paradigm has contributed to the discourse on race and racism by elevating the focus from biological determinism to a consideration of culture, values, beliefs, and worldviews. The backing of civil rights and equal opportunity helped to articulate a postWorld War II consensus in much of the United States that overt discrimination, racism, enforced segregation, and other forms of racial exclusion and bigotry were wrong and socially destructive. The casting of racial groups in an ethnic framework illuminated the ethnic dimensions of those groups: the importance and structure of family ties, religious meanings, linguistic styles, worldviews, customs, and practices.

The ethnic group paradigm has received a great deal of criticism, which over the past decades has been seen as a limited and conservative way of understanding racism. A major critique is that viewing people of color as similar to White ethnic groups does not explain the level of oppression, exploitation, and exclusion that people of color have experienced in the United States (Feagin \& Feagin, 1994; Omi \& Winant, 2014; Steinberg, 2001). It also ignores the reasons that ethnic groups emigrated (i.e., White ethnic groups migrated voluntarily while Africans were brought to the United States against their will); the reasons for leaving a host country; and the reception, resources, and social mobility available to a group in the receiving country (Schwartz et al., 2010). Genocide, slavery, loss of legal rights, and legal exclusion are qualitatively different experiences from facing discrimination, stereotypes, de facto quotas, and living in a poor neighborhood for one or two generations. Racism is not the same as ethnic discrimination; the former is more systematic, entrenched, violent, and insidious. To equate it with the negative experiences of some White ethnic groups minimizes its potency.

Another criticism of this model is that it considers Eurocentric, Anglo-American culture as the norm, and that assimilation and acculturation into this culture is a goal. If a group resists assimilation, the implication is that its members are not embracing this country and are erecting barriers to their own success and achievement. In general, this paradigm tends to center on the group's own agency and responsibility for its success or failure, neglecting an analysis of power and structural barriers that oppress and limit the opportunities of people of color. The emphasis is more on culture, and which cultural traits lead to social and economic success and which inhibit a group's advancement. More recent acculturation theorists have attempted to complicate the notion of acculturation and get away from a "one size fits all" conceptual framework (Schwartz et al., 2010). Schwartz and colleagues note that cultural similarity and dissimilarity between the immigrant group and host country, historical patterns of racism and other forms of social stratification that already exist in the host country, and factors such as whether the immigrants are refugees, asylum seekers, and documented or undocumented influence the social construction of the meaning of the group's immigration.

The new wave of acculturation theory encourages examination of the advantages that some ethnic groups have in capital, skills, connections, and power that was missing in earlier iterations of ethnic theory. What becomes problematic is when the success of one immigrant 
group is compared with that of another: Does culture breed success, or does success shape culture? An associated risk is that the alleged cultural superiority of one group becomes reified in a similar way to biological justifications of racial oppression.

A racial grouping (e.g., Black) may subsume many ethnic groups (e.g., African Americans, Haitian Americans, Jamaican Americans), which is quite different from a White ethnic category (such as Irish Americans; Omi \& Winant, 2014). Ethnic theories on their own are unable to explain the advantages or disadvantages associated with skin color, or the phenomenon of White supremacy and privilege

\section{Race Relations Theories}

The 1950s through the 1970s saw a burgeoning sociological literature about ethnic and race relations (Berry, 1958; Blaylock, 1967; Epps, 1973; Kinloch, 1974, 1979; McDonagh \& Richards, 1953; Segal, 1966; Simpson \& Yinger, 1953; Vander Zanden, 1963). Race relations theories form a broad category that encompasses many different perspectives. Some are aligned with ethnicity theorists, others focus on prejudice, and still others consider structural factors that shape race relations. What they have in common is that they recast racism as race relations. The conceptualization and concentration of study is how different ethnic and racial groups interact with one another.

Questions considered by race relations theorists include the initial contact situation between groups; how groups interact and the role of prejudice and discrimination; and the dynamics of conflict, cooperation, and competition between groups. One of the conceptual advantages of this approach is that it goes beyond viewing racism as an individual problem of prejudice or discrimination and recognizes that people have group identities, memberships, and statuses that transcend their personal situations.

These theories usually conceptualize racism in terms of majority-minority group relations; however, the definitions of majority and minority are contested. Are Jews of European descent a minority group because of their religious and cultural status, or are they a majority group by virtue of White privilege, or both? If a group is numerically superior in a community, yet its members are neither White nor of European descent, do they still constitute a minority group? Does the term minority imply less than, and, if so, does this mean that this group will always be viewed as existing peripherally to some assumed center or normative mainstream? This seems to be the case when cities with more people of color than Whites are described as "majority minority." Are members of minority groups "minorities" and what does it mean to be a minority? Who gets to define minority-majority? This formulation may burden individuals with a negative identity and can foster a sense of marginalization and alienation. It also implies a center of gravity, the perspective of the "majority" group, which in the United States is socially constructed as White.

In addition to these questions are concerns that the term race relations does not adequately describe the institutional, political, and legal basis of racism. A race relations paradigm can focus on relationships between two or more ethnic and racial groups, without acknowledging the power arrangements that shape the interactions. Prejudice and discrimination can be seen as cognitive qualities of majority and minority groups. This lends itself to viewing racism as a reflection of group attitudes and behaviors, minimizing social context. Within this framework, any group potentially can subjugate or discriminate against another group, which is theoretically possible but at odds with the arc of history: In the United States and other 
Western nations, there has been a pattern of enduring inequalities, which constructs privileged people as "White" and disadvantaged people as "people of color."

\section{Psychological Theories}

After World War II, psychologists and social scientists became more interested in understanding the nature of prejudice. Prejudice was defined as "the holding of derogatory social attitudes or cognitive beliefs, the expression of negative affect, or the display of hostile or discriminatory behavior towards members of a group because of their membership in that group" (Brown, 1995, p. 8). If prejudice could be understood, perhaps the roots of virulent racism would be exposed. How could the Jewish Holocaust have happened? How do ordinary people become complicit in such irrational, hostile, and destructive social movements? What underlying psychological dynamics were at play to explain American racism and antiSemitism? These were some of the questions that sparked prejudice theory, and research was directed to the psychological aspects of racism and the social psychology of intergroup relations. Freudian and neo-Freudian concepts were employed to further this understanding.

\section{Early Research}

Some of the most notable scholars in this tradition were Gordon Allport, Theodor Adorno and his research associates, and Ashley Montagu. They concentrated particularly on prejudice; psychological mechanisms that fueled prejudice, identity, and personality; and how all of this influenced group membership and intergroup dynamics. Allport's (1954) book, The Nature of Prejudice, still is regarded as a classic and has spawned much research on psychological facets of racism. Allport's $(1948,1954)$ work considers drives, attitudes, feelings, and defense mechanisms and how these contribute to stereotypes, prejudice, and discrimination.

This led to articulating the concepts of in-group (where a person sees commonality and sameness) and out-group (where a person perceives difference, otherness, and possible threat). In addition to psychodynamic theory, learning theory was applied to explore the mechanisms by which prejudice was learned and transmitted.

Adorno et al. (1950) were also interested in the concept of in- and out-groups. From their research, they concluded that a certain character type, an "authoritarian personality," predisposes people to prejudicial beliefs and behaviors. Utilizing Freudian concepts, they described how family socialization, particularly harsh discipline, leads to displaced aggression toward members of out-groups. Part of this dynamic is a predilection for ethnocentrism (inordinately favoring and elevating one's in-group) and the tendency to generalize about negative attributes of out-groups. This conceptual stance continues today as researchers try to explain the racism of the modern Republican Party in the United States through the authoritarian tendencies of its supporters (Reid, 2015).

Building on these insights, Montagu (1965/2001) described character traits, such as weak identity and sensitivity to social injury, that predispose people to display prejudice and participate in discrimination. These character traits, coupled with repressed anxiety and displaced aggression, lead to submerging one's identity in groups that are hostile to other groups and engage in racist or anti-Semitic beliefs and actions. Kovel (1970/2001) also used psychoanalytic theory to describe the psychological need of Whites to pinpoint a group-people of color-to view as inferior and feel aversion to, including projecting socially unacceptable drives and bodily functions on them. 


\section{Recent Scholarship}

A more recent manifestation of the search to understand the psychological mechanisms of racism is to think of it as a disease or addiction (Dobbins \& Skillings, 2000; Skillings \& Dobbins, 1991). This approach explains how White people are infected with racism and become addicted to White privilege. Surrounded by White privilege and Eurocentric biases that seem to be normative and ubiquitous, Whites develop cognitive distortions about the nature of the world and their place in it.

Some have criticized the metaphors of disease and addiction as explanations for racism. Medicalizing racism has its risks: It depoliticizes racism, depicts it as aberrant rather than normative, and implies the need for psychological or medical responses, or both, rather than social action (Wellman, 2000).

However, psychological theory helps us to understand how racism, particularly modern racism, persists. For example, the concept of defense mechanisms, such as denial and rationalization, can help to explain how Whites are able to sustain illusions, such as the belief that society is fair for all, or that racism is a thing of the past, despite every statistical measure that contradicts this (Miller \& Schamess, 2000). When confronted with realities that challenge assumptions, some Whites feel overwhelming guilt and shame or experience cognitive dissonance, which contributes to White denial of racism. Perhaps this helps to shed light on why the majority of Whites in the United States believe that they are the victims of reverse racism (Gonyea, 2017; Goodman, 2011; Walsh, 2013), a notion that is challenged throughout this book.

Psychological theories of prejudice and racism have offered important insights and opened illuminating windows. It is important to discern the psychological genesis of racism and to map how it is internalized, managed (or mismanaged), and projected onto the world as a template. Extrapolating these insights to examine how people identify with groups and how identity, drives, impulses, cognitive maps, and feelings become part of the fabric of intragroup cooperation and intergroup tensions has offered fertile seams of research and wisdom for social psychologists, anthropologists, political scientists, and other scholars.

\section{Modifying Stereotypes}

Stemming from the study of prejudice, excellent research has been undertaken about the nature of stereotypes and how to modify them. This framework sheds light on how prejudice and stereotypes become mechanisms that help White Americans rationalize their position of privilege and disparage people of color, blaming people of color, rather than racism, for their own racial oppression (Feagin \& Feagin, 2011; Miller \& Schamess, 2000). Any understanding of racism is incomplete without an appreciation for its psychological dimensions, and we shall consider this in depth in subsequent chapters.

Still, this approach is incomplete, and by itself is insufficient to grasp the scope of racism in the world today. Racism is much more than the sum of individual prejudices and attitudes; it is systemic, institutional, and sustained by a collective discourse of privilege and denigration (DiAngelo, 2018; Miller \& Schamess, 2000). Is the mistrust that Blacks feel toward Whites, after repeated negative encounters, the same as the prejudice that many Whites feel toward Blacks, some of it conscious, some of it below the surface of cognition? We think not but reducing racism to simply being a form of prejudice can open up such disparate comparisons. Also, theories of prejudice focus on what is inside of people with less attention to 
how prejudice is shaped by what is going on outside of people, culturally and in our institutions. When there is political uncertainty or if people experience the world as a dangerous, unstable, and threatening place, there is a greater likelihood of the emergence of prejudicial ideologies to explain this and that give people a greater sense of certainty and security (Fiske, 2013).

While theories of prejudice sometimes consider the imbalance of power and whether the differential lack of opportunity and access to rights and resources for people of color-essential components of racism—are included, prejudice is not adequately emphasized or fleshed out conceptually because the locus of examination is the individual and the group. Also, questions have been raised about the role of social conformity (Brown, 1995): Is prejudice solely a function of personality, frustrated drives, and family upbringing, or does it have a strong element of trying to fit with prevailing social norms? Otherwise, how can we account for the rise and fall of public expressions of prejudice and intolerance over time and the differences in these variables both across and within societies?

\section{Structural Theories of Racism}

The structural theory meta-category encompasses a diverse range of conceptual traditions in the study of racism:

- Colonialism, postcolonialism, and coloniality

- Marxist theories of class and racism

- Split labor market theories

- Economic and social opportunity theories

- Power and group conflict theories

Although they have different points of emphasis and, in some instances, challenge one another, they also overlap and share some common assumptions. We briefly describe these subsets, but first want to highlight what most of them share and how this distinguishes them from the theories mentioned thus far:

- Racism is more than the sum of individual or group prejudices. Historical, sociological, political, and economic analyses identify racism as being pervasive, thorough, systemic, and institutional.

- Like all "durable inequalities" (Tilly, 1998), racism involves "exploitation" and "resource hoarding" by privileged groups such as Whites at the expense of people of color.

- This leads to widely divergent opportunities for White people and for people of color, where people of color have less access to jobs (particularly well-paying jobs), a range of residential neighborhoods, quality schools, political office, and other positions of power and influence in society.

- The experience of people of color is qualitatively different from that of White ethnic groups in the United States. Racism and racial oppression are more than merely ethnocentrism and discrimination.

Postcolonialism recognizes the structural legacies of colonialism (Badwall, 2016). Colonialism was a system of exploitation and domination that lasted for centuries and created wealth for colonial powers while subjugating those living in "colonies," which included 
destroying and suppressing local political and economic systems and cultural practices; extracting and hoarding resources; ethnic cleansing; enslavement; and genocide. The structure of colonialism persists to this day in the form of wealthy so-called first-world nations and poor, developing countries. Colonialism was legitimized and enabled by racist ideologies comparing the colonized subjects to children, justifying the "White man's burden" of paternalistic rule. Racism in the United States is a legacy of colonialism, beginning with genocide of indigenous people; enslavement and forced migration of African Americans; and ethnic cleansing, violence, terrorism, exclusion, and suppression of Latinos living in what is now the United States along with people from Asia and Central and South America.

Whether comparing developing with developed countries, or Whites with people of color, people of European heritage are in positions of power and privilege relative to people of color living in former colonies or in the former colonial powers. Postcolonialists argue that Whites maintain an economic advantage by exploiting the labor of people who have limited economic options and, therefore, are coerced into working for low wages (Blauner, 1969; Feagin $\&$ Feagin, 1994), often accompanied by social isolation and cultural stigmatization. Those who are oppressed are forced into having contact with their oppressors; indigenous culture is decimated as part of the process of suppression and subjugation, and racism ultimately is employed as an ideology to justify it (Blauner, 1969).

A contemporary theoretical orientation that captures the enduring legacy of colonialism is "coloniality." Although colonialism and its ruling structure no longer exist in the same form, the hegemonic power structure embedded in the contours of society continues to control all social relations and is known as coloniality of power (Quijano, 2007). Coloniality of power utilizes White supremacy to arrange a social hierarchy that overvalues Whiteness and devalues non-Whiteness. The matrix that makes up the coloniality of power comprises White supremacy, patriarchy, capitalism and Christianity (see Figure 2.1). Together, they create a power structure that subjugates nondominant social identity groups while legitimizing the hegemony of the dominant groups.

According to Fanon (1967), White supremacy is a system of valuation utilized to force nonWhites to occupy the "zone of non-being" and Whites the "zone of being." Categorizing nonWhites as non-being not only relegated them to an inferior status but to a status of non-human. Similarly, patriarchy ascribed a higher status to men over women with the exception of nonWhite men (Grosfoguel, 2011). As a result, White women garnered more value and privilege than those with darker skin, who were forced to assume an identity of slave. This social order dictated how power was distributed determining what kind of work was valued and performed by whom. Along with gender and race, other social categories such as class and religion have within them a dominant and subjugated status established by the coloniality of power. Superior status is assigned to those individuals who conform to the values, norms, and social roles of those in power. Those with inferior status are acknowledged as "other." The coloniality of power is also the substructure that informs our understanding of intersectionality (Grosfoguel, 2011).

\section{Economic and Class Issues}

Other structural theorists emphasize economic and class issues (Omi \& Winant, 2014). Racism is viewed not as a central, independent social process but, rather, as an outgrowth of capitalism and a complicating factor in the exploitation of all workers. Instead of workers 


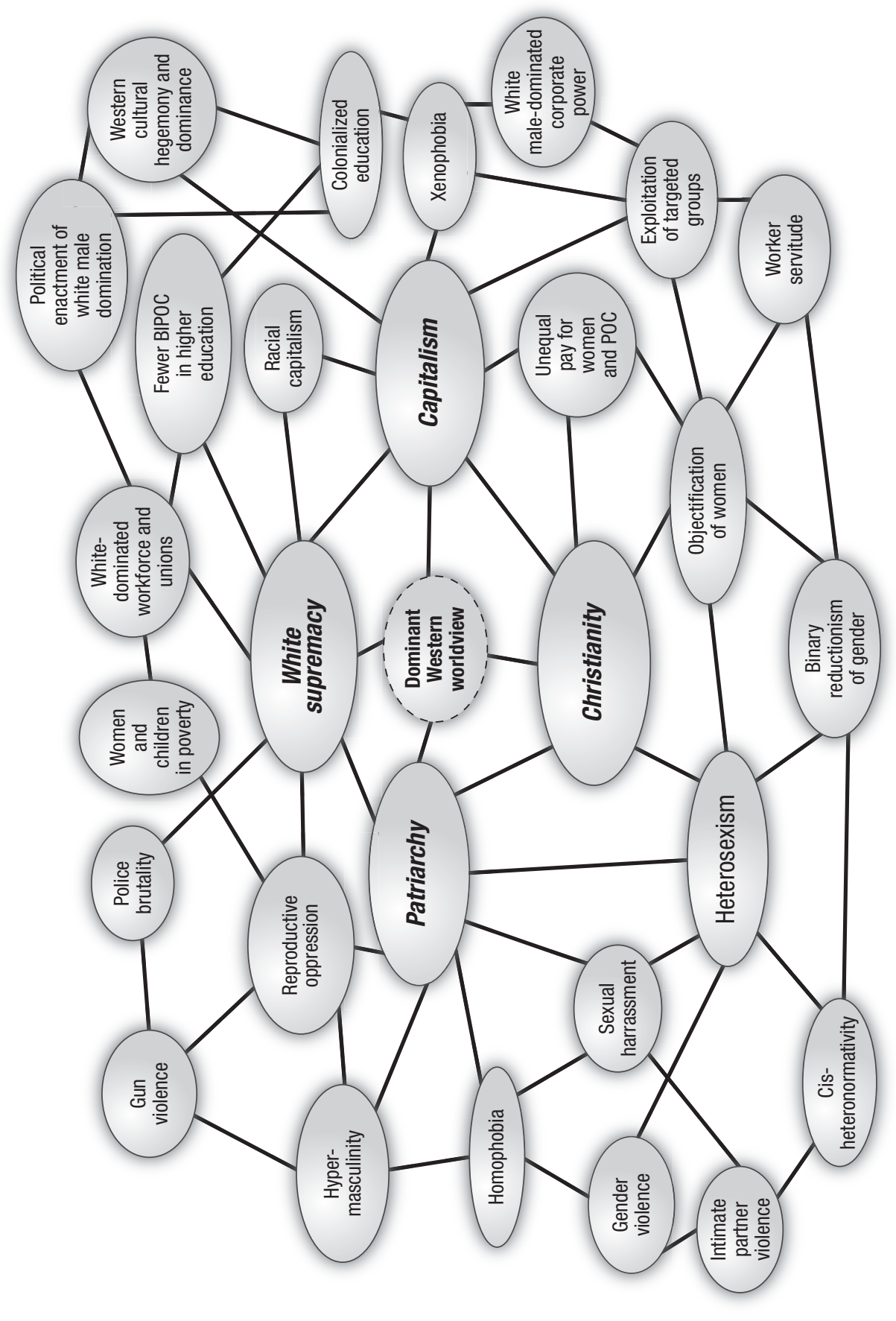

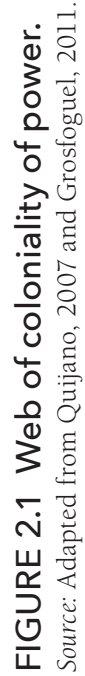


making common cause with one another across races, together advocating for their rights and benefits, racism offers the lure of White privilege, which splits the working classes.

Relative to people of color, White workers have higher status and advantages in securing occupational niches, from which they expend energy on protecting, rather than fully recognizing and challenging, their own areas of social disadvantage. For example, the history of trade unions in the United States has been one of discrimination by White workers against people of color and women (Schiller, 1998), although there have been recent efforts by trade unions to become more inclusive and less discriminatory. Allen (1994) has described how the practice of dividing indentured servants and laborers from one another during colonial times led to the "invention of the White race," a social identity that divided people sharing common economic interests, in response to the threat of economic and social disorder posed by alliances between poor Whites and present and former slaves.

Some structural theorists emphasize social stratification, status, economic opportunity, mobility, and access to resources (Omi \& Winant, 2014). The role of the state in maintaining social divisions is part of this analysis. The mismatch between skills and available jobs-as well as lack of access to the places where jobs are located because of residential segregation, social isolation, the movement of jobs from cities to suburbs, and poor public transportationcreate large swaths of severely disadvantaged people of color, particularly African Americans, Puerto Ricans, and other Hispanic groups living in older urban areas (Wilson, 1973, 1987, 2011).

When members of these communities do have jobs, many are in the service sector or in the "secondary" labor market (Schiller, 1998)—under-the-table or illegal work-which is unregulated, is poorly paid, lacks benefits and standards for occupational health and safety, and does not lead to occupational mobility in the primary labor market, where most workers hold jobs. The emphasis on the interaction between class and race is extremely important for a complex understanding of racism. This includes recognition of the economic and social burdens of racism for large segments of people of color, as well as the costs of racism for poor and working-class White people.

\section{Criticisms of Structural Theories}

Scholars of racism in the structuralist tradition have contributed greatly to our understanding of the pervasiveness of racism and how embedded it is in institutions, the economy, the political system, and society at large. More than any group, structural scholars have mapped out the contours of institutional racism.

A criticism of those who downplay race and emphasize class is that everything cannot be reduced to class conflict (Omi \& Winant, 2014). Racism is a force in its own right and, though perhaps intertwined with class exploitation, operates at all levels of society. Many middle- and upper-middle-class African Americans experience racism regularly in the workplace and in their communities (Cose, 1993); moving up in class does not dissolve racial oppression. Marxists have also been criticized for not sufficiently taking race into account in their structural analysis (Yancy \& Mills, 2014). And although coloniality and domestic racial oppression are analogous, they are not exactly the same. Most people of color are U.S. citizens and, at least in formal law, have the same rights as other citizens, although this does not translate into equal treatment under the law. 
Seemingly race-neutral laws and policies, such as drug-sentencing laws and transportation policy, disproportionately discriminate against and encumber people of color. Another criticism is that structuralist explanations can be too deterministic and do not acknowledge the agency of oppressed people and their capacity to form cultures of resistance (Omi $\&$ Winant, 2014).

Describing the social and economic lines of racism is essential, yet incomplete. In addition to being a structural form of oppression and exclusion, racism is also an ideology shaping public discourses. There are many meanings, signs, and symbols that convey, represent, reproduce, and transmit racism through decades, even centuries, and across regions and communities. Racism in the media, for instance, is not solely about ownership and whose interests are represented (as important as these are) but also concern over what assumptions and stereotypes are embedded in projects, as well as what is ignored and left out. And racism-as scholars of prejudice have articulated-involves attitudes, emotions, and intergroup dynamics.

Though many people would argue that racism today is less blatant and subtler than it was 50 years ago, an increase in open acts of violence throughout the country, including racially motivated attacks on churches and mosques and the murders of Black people by law enforcement officers, during the past decade clearly challenges this idea. Racism remains a damaging force. There continues to be aversive racism (Dovidio et al., 2002, 2001) and racial microaggressions (Solorzano et al., 2000). Racism is a "project" that is constantly shifting and migrating, and "racial formation [is the] socio-historical process by which racial categories are created, inhabited, transformed and destroyed" (Omi \& Winant, 2014, p. 55). Racism has subjective as well as objective dimensions, and this is captured in critical race theory and critical realism to which we now shall turn.

\section{Critical Theories}

There have been a range of critical theories — critical legal theories, critical feminist studies, queer studies, gender theories, as well as critical theories about racism. We will focus on two critical theories that we find useful for helping professionals: Critical Race Theory (CRT) and Critical Realism (CR).

\section{Critical Race Theory}

CRT is founded on the premise that racism has been central to the formation and structuring of the United States, which leads to certain questions. If race is not biological, then what does it mean? How does the way that race is constructed change over time? What are the social, economic, legal, and political implications of how race is constructed? What are the prevailing discourses surrounding race and racism? What is centralized and marginalized in the interrogation of race and racism, visible and invisible? What is outside, concrete, and observable about racism; what is internal and subjective; and how do the public and the personal interact? What can be done to dismantle racism?

These are some of the questions explored by critical race theorists, a loose amalgamation of scholars and social activists. Although the origins of CRT are traced to the late 1970s (Delgado \& Stefanic, 1997), there has been an outpouring of books and articles under this umbrella since the 1990s. The impetus for the development of this paradigm was an attempt to reconceptualize and reformulate the understanding of race and racism that had become 
common wisdom as a consequence of the Civil Rights Movement. Many people committed to ending racism wanted to grasp this phenomenon in a complex, holistic fashion that would contribute to more effective amelioration.

The primary inspirations for this new approach were critical legal studies, critical sociology, and postmodernism (Delgado \& Stefanic, 1997). Scholars (McDowell \& Jens, 2004; Solorzano et al., 2000) have identified the following five common strands of CRT:

1. The significance of race and racism in U.S. society and how this intersects with other forms of social oppression

2. The importance of deconstructing and challenging dominant racial ideologies, which normalize racism

3. A commitment to racial and social justice

4. The importance and validity of learning from experiential knowledge and recognizing the unique perspectives of people of color

5. The use of an interdisciplinary perspective to understand race and racism

Esposito and Murphy (2000) add that knowledge, understanding, and meaning evolve from intersubjective processes: the interaction of personal meaning systems with historical and social realities and identities, discourses, and connotations drawn from the interactions of racial groups, where race and identity are always relational.

Omi and Winant's germinal work in 1992, Racial Formation in the United States: From the 1960s to the 1990s, Third Edition (2014), helped to reconceptualize the meaning of race and its implications for racial formation in what the authors referred to as the American "racial project." They described race not as a fixed, essentialist entity but, rather, as a historically determined, fluid, unstable, contested social construction, continually being deconstructed and reconstructed.

The meanings of race change over time and in different social contexts. For example, Jewish, Irish, and Italian people were considered racial "others" when they first immigrated to the United States, but over time were socially constructed as White (Guglielmo \& Salerno, 2003; Ignatiev, 1995; Sacks, 1996).

As Winant (1997) has stated, race is real and illusory; it can both establish and deny one's sense of identity; racial categories can neither be frozen and reified nor completely dissolved. The process of racial construction is not only social and psychological, but legal as well. Some "requisite cases" in U.S. jurisprudence have struggled to define "White" and "Caucasian" by law, allegedly drawing on biological sciences and common sense (Lopez, 1994, 1996; Taylor, 1997). Laws such as these literally have shaped how the population looks, by defining who could enter the country and become a citizen and by prescribing who could and could not intermarry (Lopez, 1996).

Race is a social construction necessary to racism, which has a concrete existence and impact, as well as profound social and psychological consequences. Racism is neither accidental nor an inevitable process. It arises from human ideas, actions, and interactions and is part of a complex human web of interactions imbued with social meanings (Lopez, 1994). Memmi (2000) has described the construction of race and racism as a four-part process:

1. A group of people is perceived as being different (physically, culturally).

2. Value is placed on such differences; the "other" group is thought of as being less advanced, less worthy, less civilized, less trustworthy, and, in some instances, not fully human. 


\section{Racism in the United States}

3. The negative differences are generalized to all members of the group.

4. All of this is used to dominate, oppress, and marginalize the targeted group.

Although this is a helpful way to conceptualize the dynamics of racism, we also must recognize the strengths and agency of targeted groups despite these forces and their capacity to resist and undermine dominant racial discourses and racist practices.

This description of racial oppression acknowledges the interaction of psychological and social dimensions, integrating concepts from structural theorists and scholars of the dynamics of prejudice. In a racialized society, we all have racial identities whether we wish to or not. Our sense of ourselves as racial beings and our consciousness about this informs our perceptions of others and social actions (see Exercise 2.2). White people, who have little awareness of White privilege, inhabit a rarefied world by gliding through life without encountering the closed doors or hurdles that people of color navigate daily. This shapes worldviews, values, judgments, behaviors, and beliefs about what is true and fair. One implication, drawn from CRT, is that an interrogation of White privilege and supremacy, and what it means to be White, is necessary when confronting racism. Often, books about race and diversity focus on people of color rather than considering what it is like to live as a White person in a racialized society.

\section{Racial Contract}

Critical race theorists also investigate how racism is encoded in institutions, organizations, cultural practices, and the everyday interactions of people. Racism is so ubiquitous and endemic to the fabric of social life that it appears to be ordinary and, for some White people, invisible. The familiarity and imperceptibility of racism for many White people is sustained by a public, cultural discourse that subjugates and marginalizes narratives of racism. Racism is reduced to egregious acts of personal prejudice and bias. Whiteness and European culture are elevated to "normal" stature, placing other cultures and people of color in a status of "minority," located on the borders, as deviations from the center.

One way to understand this dynamic historically is that a "racial contract" has existed from the inception of European colonialism and is encoded in the nation's social contract (Mills, 1997). The racial contract from the beginning determined who was fully human and who was considered to be "savage," "inferior," and not fully human. It determined who had the rights of full citizenship and who was denied those rights. According to Mills (1997), the racial contract is the reality that underlies the lofty ideals and aspirations of the social contract-for example, "all men are created equal"-words written by slaveholders. The contract structured all of society: what is permissible, what is fair, what is normal, what can be debated, and what is rendered invisible or unthinkable.

Mills calls this an agreement to "misinterpret the world," the legacy of which obfuscates and obscures the nature of reality for those who benefit directly from the contract. This leads to White people acting and behaving in ways they believe are ethical and moral without being able to see how they themselves are, consciously or unconsciously, complicit in maintaining a society that benefits them while disadvantaging others-an idea that they would abhor in the abstract. This process sheds some light on how White people, who continue to benefit from the racial contract, believe that they are the targets of modern racism (Gonyea, 2017). 


\section{Deconstruction and Reconstitution}

Critical race theorists are engaged with re-examining and rethinking dominant historical and social narratives. Due to the "racial contract" there are collective cognitive maps and discursive narratives, internalized by many, which centralize and normalize Whiteness and White supremacy. Thus it is important to deconstruct and reconstruct the meaning and understanding of racial categories. Thus CRT seeks to map out subjective states of mind and identity and to link them with the social realities experienced by the targets of racism, which are invisible to so many White people.

CRT leads us to explore and understand the experience of being socially targeted, as well as being socially privileged, and how this shapes and influences social identity. It urges us to examine the hidden "dissensus," veiled by a dominant discourse of accord and consensus (Leonardo \& Porter, 2010). Within CRT is a call to action, a recognition that we are not neutral observers but, rather, embedded actors, woven into the social fabric and therefore able to make choices about what we accept or do not tolerate, what we ignore or decide to confront, and whether we are bystanders or social activists.

\section{Critical Realism}

CR was developed by Roy Bhaskar as a philosophical approach in the natural sciences, to counter both positivism and postmodernism (Archer et al., 2013). Its principles have since been applied to a number of different disciplines including ethics and social science. Critical realism posits that an objective reality does exist, and it is composed of three levels: "the empirical level consisting of experienced events; the actual level, comprising all events whether experienced or not; and, lastly the causal level embracing the 'mechanisms' which generate events" (Houston, 2001, p. 850). Understanding that the causal level is still real, though not always perceptible, is crucial, as it affects the events occurring on all levels. Without an understanding of the causal level, enactments of social oppression, such as racism, will continue unabated. Archer et al. (2013) offer the concept of magnetism to illustrate the causal level, and its ability to affect the empirical - a mechanism that, though unseen, has real and unyielding influence. CR also describes the world as a set of systems whose influence on one another is variable, significant (or insignificant), and unpredictable. In other words, systems do not operate in a vacuum; they interact with and influence one another, as with intersectional oppressions and identities. Although internal systemic tendencies may exist, multiple systems are operating simultaneously (Houston, 2001) and without a set pattern. Human systems are described as complex due to the countless social and psychological factors that exact influence on individuals and groups at any given time and every given moment.

Using this lens, racism can be seen as a system occurring at the causal as well as the empirical levels; it is a force that has significant influence on all facets of human experience. Hegemonic systems such as White supremacy, patriarchy, Christian-centrism, are unseen mechanisms that construct the empirical and actual levels of experience such as discrimination, racism, sexism, Islamophobia, and anti-Semitism. Often, we presume that unseen oppressive forces influence in one direction only; the oppressor impacting the oppressed. However, as Houston (2001) makes clear, when applied as a social theory CR does not presume individuals to be merely victims of these unseen mechanisms without recourse. Rather, just as these forces impact a group that is targeted, that group can in turn can impact those forces. 


\section{Racism in the United States}

Applying critical realist terms, we can understand racism, as comprising three levels: the causal, actual, and empirical. At the causal level power structures serve as unseen forces that shape social life and co-opt differences to create social hierarchy. Such forces include White supremacy, patriarchy, and colonialism (coloniality). In the United States, these interrelated social suprastructures pervade all aspects of social, cultural, political, and economic life. At the actual level these social forces are mechanized through institutions, interactions, selfperceptions, and cultural norms. Privilege, microaggressions, cultural appropriation, residential segregation, and social marginalization are all examples of actual manifestations of White supremacy, colonialism (coloniality), and patriarchy. These physical, socio-political, economic, and cultural structures exist whether or not an individual actor consciously experiences them. We can recognize their existence through our empirical experiences, either personally or in aggregate. Personally, we have empirical experiences informed by racism. Racism is manifested when, for example, one lives in a neighborhood that has been decimated by economic and political divestment. It is present when one strives to attain a standard of beauty that sexually subjugates women and norms beauty to Whiteness. It is also evident when accessing the benefits of privilege by, for example, engaging in self-deception associated with the myth of meritocracy. There are countless empirical examples of racism that impact our everyday lives.

Empirical manifestations of racism can also be visible at the aggregate level. The aggregate empirical level illustrates group patterns as well as individual experiences. For example, racial disparities in health reveal the collective effects of racism on groups of color, as do gender and race-based wealth and wage gaps. Mass incarceration of men of color provides empirical evidence of the aggregate consequences of systemic racism within the policies and practices of law enforcement and the criminal justice system (Alexander, 2010). Tracing one specific form of racism through the various levels explicated in critical realism helps to articulate this framework. In the United States, farm workers from Mexico and Central America often work under exploitative and oppressive conditions. At the empirical level, exploited farmworkers directly experience oppression. They may live in substandard housing conditions (Arcury et al., 2012; Quandt et al., 2013), be exposed to toxic chemicals (Arcury et al., 2001; Robinson et al., 2011), have limited bargaining power (Telega \& Maloney, 2010), encounter sexual harassment (Waugh, 2010; Murphy et al., 2015), and lack job security (McLaughlin \& Hennebry, 2013). If the farmworkers have access to aggregated information regarding labor abuses in the agriculture sector, they may see that the issues they have encountered do not just impact one or two farms. These issues are present at many farms in many locations (Farmworker Justice, 2017). The actual level consists of the cultural norms, institutions, and practices which solidify power in the hands of agribusiness leaders and away from the worker. This includes laws and policies that perforate the labor rights of farmworkers (Ramos, 2017) and racialized narratives that permit the marginalization of Latinx workers (Nelson, 2008). Capitalism also works at the actual level, creating fundamental structures that commodify labor and demand the extraction of surplus cheap labor of many for the profit of few. Finally, the unseen mechanism at work behind all of this is White supremacy, which denigrates people of color and rationalizes their mistreatment and coloniality (Quijano, 2007), which recasts indigenous land as a natural resource to be manipulated for profit, augmenting the justification for exploitation.

We draw heavily from CR and CRT, although we also utilize elements of all the theoretical approaches summarized in this chapter. 


\section{THE CONTOURS OF RACISM}

We conceptualize racism as existing along a spectrum, with many different types and forms. Part of the confusion about racism-as the introductory vignette to this chapter illustratesis that the term is used to describe many different phenomena and is laced with multiple meanings. There are different levels of racism, direct and indirect racism, intentional and unintentional racism, varying sites of racism, and a range of frequencies of racism. We describe these contours briefly before presenting the spectrum of racism.

\section{Levels of Racism}

Racism traditionally has been viewed as having at least three levels: (a) individual, (b) group, and (c) institutional. Individual racism refers to biases, prejudices, beliefs, or actions that participate in or collude with racism. An example of individual racism is demonstrated by a person who harbors stereotypes of inferiority or difference toward a person who is a member of a group that is different from their own, which leads to exclusionary behaviors or actions, or even telling racist jokes. It can also lead to law enforcement officers using lethal force more quickly when confronting young men of color.

Group racism alludes to actions on the part of one group-often referred to as a dominant, privileged, or agent group-that discriminates against, marginalizes, or in any way oppresses another group that is constructed as being racially different. An example is when White ethnic groups formally and informally control a residential area and will forcefully resist having an ethnic group of color integrate the neighborhood. Another example is the predominantly White composition of many police forces in communities with high numbers of people of color.

Institutional racism indicates systemic, societal, durable racism that is embedded in institutions, organizations, laws, customs, and social practices. Institutional racism forms a web that blocks opportunities for some while offering privilege to others. It leads to a cumulative effect in which groups that are racially targeted are excluded from living in certain neighborhoods and working in numerous jobs and professions, have less access to social assets such as quality schools, and incur greater health risks and other negative consequences and outcomes because of a variety of interacting legal, illegal, direct, and indirect practices. Institutional, group, and individual racism combine when men of color are stopped more frequently than White men by White police officers working in predominantly White police forces and who are more likely to use lethal force.

A final level of racism, ideological racism, is pervasive and interwoven into social discourses and narratives. Virulent ideological racism has been enacted throughout history and across the globe through hateful and degrading messages, such as about Muslims in Kosovo by Serbs, Tutsis in Rwanda by Hutus, and Jews in Nazi Germany, and is used to justify horrendous actions against a racial or ethnic group. A modern U.S. example is the vitriol expressed by former President Trump against Muslims and immigrants. By contrast, subtle ideological racism is so familiar that it often passes unnoticed, yet it sustains stereotypes or discriminatory practices. Former President Trump often engaged in this form of racism as well, such as his Tweets about how "no human being" would want to live in Baltimore, implying that those living in Baltimore are not fully human. Ideological racism can be used to reinforce or justify any of the levels of racism mentioned here. 


\section{Direct and Indirect Racism}

Some racism is overt and direct. Examples of this were the Jim Crow laws and practices in the southeastern United States, which prohibited African Americans from riding in the front of buses, from voting, and even from using the same water fountains as White people. Direct, overt racism can occur at any level. An individual can actively and directly express racial bias or discrimination toward another person and cause bodily, emotional, or psychological harm to the target of racism.

Indirect, or covert, racism seems on the surface to be more passive, but in practice it serves to sustain and maintain racism. An example is seen in the attitudes and biases that inhibit homeowners in a predominantly White suburb from selling their homes to people of color. The cumulative effect can be a segregated neighborhood. Another example is the difference between sentences for possession of cocaine versus crack cocaine, which have no overt indication of racial bias, yet carry the consequence of African Americans being incarcerated disproportionately, more frequently, and for longer periods than their White counterparts.

\section{Intentional and Unintentional Racism}

Intentional and unintentional forms of racism are related to active and passive types of racism. The important variable here is motivation. The men who murdered James Byrd, Jr., in 1998, tying him to a vehicle and dragging him along the roads of Jasper, Texas, consciously tortured him because of his race. But many well-intentioned and well-meaning White people engage in racist behaviors of which they are unaware unless confronted. This often comes from unexamined stereotypes or attitudes and consequent microaggressions.

For instance, a White professor, when talking about poverty or single parenthood, may direct her gaze consistently to African American students in the class-a behavior of which she and many White students are unaware but is painfully evident to most African Americans in the class, as well as some White students.

Leong (2012) discusses the concept of racial capitalism; a practice that can include either intentional, unintentional, or both forms of racism. Long offers an examination of a practice where non-Whiteness is valued as a commodity within individual or institutional practices that seek to elevate their own value or value of their institution. Diversity itself has become a valued commodity and most often refers to having Black, indigenous, and people of color (BIPOC) individuals become participants in a predominantly White group or institution. As a result, many institutions intentionally look to hire or accept people of color (POC) in order to be attractive both to White individuals who wish to be in a diverse environment and to POC individuals who do not wish to be the only person of color in an institution. This valuing of non-White racial identity, solely because of the benefits it affords a predominately White institution is racial captialism. That is not to say that diversity does not have its merits or that attempts to achieve it are inherently racist. What must be examined is the real objective of an individual or institution.

If the rationale for diversity is only valued to the extent to which it benefits White people, it is commodifying non-Whiteness and has no intention of including POC in the institution's power structure. In this example, the perception is that by merely having POC present, they are, in fact, included. However, the reality is, POC can be present without being included. A desire for diversity that emerges from a belief that remediation is necessary to right the 
wrongs of past racial discrimination certainly brings with it an intent toward racial justice. Yet, either way, it is the predominantly White institution that possesses the power to place value on non-White identities. What this reveals is that progress for POC in these instances only occurs when it benefits Whites. In order to avoid participating in racial capitalism, when an individual or institution has racial diversity as a goal, they must simultaneously create a plan for how POC individuals will be included in the power structure and supported by the institution.

\section{Sites of Racism}

Racism occurs in many different places — on highways when dark-skinned people are stopped "randomly" by the police while light-skinned people drive by; in classrooms, courtrooms, neighborhoods, and streets where White people are more predominant or in positions of power; in television shows and the nightly news, where White people dominate as producers and presenters; in mental health agencies where White people are often in positions of authority and power, even in agencies predominantly serving people of color; in conversations between White people where racial stereotypes and norms or White privilege and supremacy are reinforced backstage; in segregated or racially homogenous neighborhoods; in the privacy of people's homes. Racism operates in all units of society, public and private, institutionally and individually.

\section{Frequency and Magnitude of Racism}

Frequency and magnitude refer to the incidence and scale of racism. Is it an everyday occurrence, a legacy that has persisted for decades, or an isolated incident? Does a television show consistently portray Asian Americans in a stereotypical fashion, or did a typecast emerge in a single episode? Is the racist narrative conveyed in a news discussion a part of the network's pervasive culture or a reflection of an individual editor and presenter? When analyzing racism and how to respond to it, an analysis of the frequency and magnitude of racism is useful, and using CRT to identify the hidden patterns and drivers is essential.

\section{THE SPECTRUM OF RACISM}

Racism does not fit into neat, exclusive categories. Individual and institutional racism coexist side by side and are interactive; they potentiate one another. The racist attitudes of individuals become reified in institutions, and racist institutions normalize prejudice and oppression, shaping the way in which individuals view the world. Societally, racism is a fluctuating, shifting process, with many examples of societies that have been at the extreme end of the spectrum of oppression during certain eras but not during others. However, when racism and White supremacy are part of a society's history, they will usually re-emerge even if they had seemed to wane. Exercise 2.3 can help with the application of concepts related to the spectrum.

The United States has experienced all of the types of racism described by the spectrum. The spectrum of racism has a core set of practices and a range of levels, as shown in Figure 2.2. The bottom line indicates the level of racism, ranging from the intrapsychic/intrapersonal, to the interpersonal, through the institutional, to the societal/nation state. 


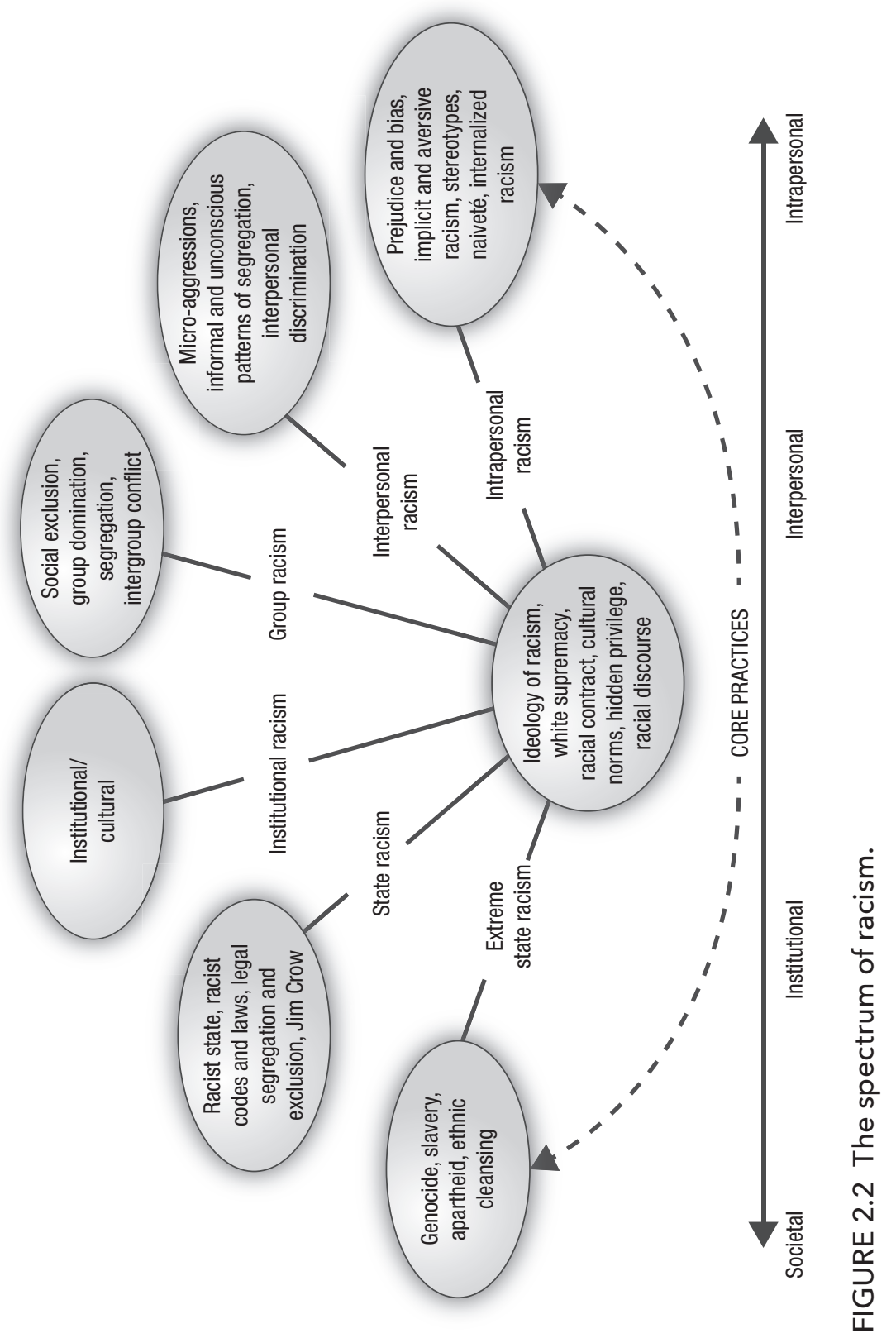


In the center of the spectrum is the core, consisting of a racial contract, an ideology of racism, cultural norms, and the oftentimes hidden, invisible privileges of those who benefit from the advantages of the racial contract. The core of racism is part of any facet of the spectrum. The heart of racism is what powers any type or form of racism. Like a human heart, it pumps blood to the various regions of racism, and from them the blood returns.

\section{Intrapersonal}

At the intrapersonal end of the spectrum are prejudice and bias, attitudes, beliefs, emotions, ideas, and cognitions. These ideas and responses are what we think of when we see a news story about an armed robbery or what we feel when we pass someone on the street. They are at the core of our internal process and form a reservoir for the stream of messages that we have received from birth, from parents, books, teachers, songs, films, and pictures-messages as ubiquitous as the air we breathe. Our absorption of these messages leads to internalized stereotypes, some of which we are aware but many others of which are unconscious. These stereotypes, in turn, can be a repository of internalized superiority or inferiority-what sometimes is referred to as "internalized racism."

\section{Interpersonal}

At this point along the spectrum, we see racism expressed in interactions between people. Racial "microaggressions" occur, unintentional acts of racism often unrecognized by the perpetrator but agonizing and hurtful to the target of the interaction. Or intentional hostile acts take place, resulting in many potential levels of injury. The challenges of having respectful and meaningful interracial conversations and dialogues lead to poor and missed communications. Interpersonal levels of racism create tensions in the workplace and social isolation and even violence in the community.

\section{Intergroup}

Intergroup racism refers to the place on the spectrum where people identify with groups defined by socially constructed racial categories. The act of identification shapes the formation of racial identity, and the collective interactions of group members result in domination, exclusion, discrimination, and other forms of group-based oppression.

This level of racism can be manifested in voting patterns and support for voter suppression laws that disproportionately impact members of another racial group, competition for jobs and neighborhoods, and marriage and friendship patterns. This is not a playing field of equals; one group (Whites) has more power, resources, and privilege and exercises this advantage at many levels of interaction and patterns of behavior that appear to be racially neutral and "the way things are."

\section{Institutional}

Institutional racism is well documented and is discussed at length in Chapter 5. Institutional racism leads to exclusion from neighborhoods, jobs, schools, politics, healthcare, and mental healthcare; greater exposure to environmental hazards; higher risk of arrest, incarceration, and lethal force; and lower life expectancies. We also include dominant cultural patterns of 
prejudice and oppression as a form of institutional racism. Institutional racism can occur in any form of society, including democracies.

\section{Official and State}

Official and state racism describes situations in which the state is overtly racist. Examples of this, unfortunately, abound. This level of racism includes state-sponsored racism at any level of government. Legal segregation, racist codes and laws, and Jim Crow are all forms of statesponsored racism that are part of U.S. history. Recently, the U.S. Supreme Court has affirmed the rights of states to racially gerrymander political districts and impose voting restrictions that disproportionately affect voters of color. As long as the policy or law has the veneer of being race neutral, it has been ruled acceptable by the current Supreme Court, despite having documented racialized consequences. Not only has the court allowed practices that disenfranchise people of color from the right to vote, but also those that result in them disproportionately and disastrously being the victims of racial discrimination in the criminal justice system (Alexander, 2010).

\section{Extreme, State Sanctioned}

The gloomiest, most appalling end of the spectrum of racism is at the state-sanctioned extreme. Examples include genocide, ethnic cleansing, slavery, and racial apartheid. All of these are part of U.S. history and, sadly, these forms of racism persist in the world to this day. The profound cruelty and terrorism of slavery and the attempts to exterminate indigenous people cannot be glossed over or seen merely as past practices; their legacy persists to this day and is the foundation for the "causal" level of enduring manifestations of White supremacy.

\section{CONCLUSION}

In this chapter, we have traced the historical underpinnings of the notion of race and explored the many meanings and interpretations of racism. Various theories of race and racism have evolved, and this chapter highlights several. We have offered a "spectrum of racism" to incorporate the many forms and levels of racism in the United States.

Our understanding of racism, both complex and comprehensive, should not leave us feeling hopeless or overwhelmed. Racism, in its most virulent manifestations, such as during the period of U.S. history when slavery was legal, has been undermined, dismantled, and delegitimized. But racism and White supremacy are always lurking in the shadows, functioning as hidden drivers, and can re-assert themselves in a full-blown way at any moment. The work ahead is hard and challenging, progress is often painfully slow, and we must often take the long view, but the stakes are high and the risks to us all by remaining bystanders and not taking action are even higher.

\section{EXERCISE 2.1 Conceptual Frameworks and You}

Consider the different theoretical frameworks presented in this chapter. Which ones best help you to understand the nature of racism? What questions do they raise for you that are 
still unanswered? Are there any views or assumptions that you hold that were challenged by these theories? Were there any feelings that came up for you while you read about them? What is your theory of racism? If you were explaining to another person the nature of racism, what would you include in a 5-minute presentation?

\section{EXERCISE 2.2 Colonialism and Your Group}

Discuss the following question in pairs: Which ethnic and racial group(s) do you identify with? List the ways that coloniality benefited your group and the ways that it harmed or hindered your group. Share this with your partner. Discuss whether and how colonial legacies continue to shape your lives in explicit or subtle ways.

\section{EXERCISE 2.3 Applying the Spectrum of Racism}

1. Take each type of racism from the spectrum of racism and apply it to either a current or a historical situation. Consider what types of racism exist in your hometown, college, or university; worksite; website; the United States at large; and other parts of the world. What levels of racism are present in each example (individual, group, institutional)? Can you identify direct and indirect types of racism in your examples? What specific sites of racism are evident in the examples? Note the frequency and magnitude of racism described in your examples.

2. After completing the exercise, reflect on what thoughts and feelings emerged for you as you applied the spectrum of racism. Were any of these reactions surprising or unexpected? Were any parts of this exercise particularly difficult? What questions about racism has this exercise raised for you?

\section{REFERENCES}

Adorno, T. W., Frenkel-Brunswik, E., Levinson, D. J., \& Sanford, R. N. (1950). The authoritarian personality. Harper.

Alexander, M. (2010). The new Jim Crow: Mass incarceration in the age of colorblindness. The New Press.

Allen, T. W. (1994). The invention of the white race. Verso.

Allport, G. W. (1948). The ABC's of scapegoating. B'nai B'rith Press.

Allport, G. W. (1954). The nature of prejudice. Addison Wesley.

American Anthropological Association. (1998). AAA statement on race. American Anthropologist, 100(3), $712-713$.

Angier, N. (2000). Do races differ? Not really, DNA shows. New York Times. www.nytimes.com/library/ national/science/082200sci-genetics-race.html

Archer, M., Bhaskar, R., Collier, A., Lawson, T., \& Norrie, A. (Eds.). (2013). Critical realism: Essential readings. Routledge.

Arcury, T. A., Quandt, S. A., Cravey, A. J., \& Elmore, R. C. (2001). Farmworker reports of pesticide safety and sanitation in the work environment. American Journal of Industrial Medicine, 39(5), 487-498.

Arcury, T. A., Weir, M., Chen, H., Summers, P., Pelletier, L. E., Galvan, L., Bischoff, W. E., Mirabelli, M. C., \& Quandt, S. A. (2012). Migrant farmworker housing regulation violations in North Carolina. American Journal of Industrial Medicine, 55(3), 191-204. 


\section{Racism in the United States}

Badwall, H. (2016). Critical reflexivity and moral regulation. Journal of Progressive Human Services, 27(1), $1-20$.

Berry, B. (1958). Race and ethnic relations. Riverside Press.

Blauner, R. (1969). Internal colonialism and ghetto revolt. Social Problems, 16, 393-408.

Blaylock, H. M., Jr. (1967). Towards a theory of minority-group relations. Wiley.

Brown, R. (1995). Prejudice. Blackwell.

Cartmill, M. (1999). The status of the race concept in physical anthropology. American Anthropologist, 100(3), 651-660.

Cose, E. (1993). The rage of a privileged class. HarperCollins.

Delgado, R., \& Stefanic, J. (1997). Introduction. In R. Delgado \& J. Stefanic (Eds.), Critical white studies: Looking behind the mirror (pp. xvii-xviii). Temple University Press.

Diamond, J. (1997). Guns, germs and steel: The fates of human societies. W.W. Norton Publishing.

DiAngelo, R. (2018). White fragility: Why it is so difficult for white people to talk about racism. Beacon Press.

Dobbins, J. E., \& Skillings, J. H. (2000). Racism as a clinical syndrome. American Journal of Orthopsychiatry, 70(1), 14-27.

Dovidio, J. F., Gaertner, S. L., Kawakami, K., \& Hodson, G. (2002). Why can't we all just get along? Interpersonal biases and interracial distrust. Cultural Diversity and Ethnic Minority Psychology, 8(2), 88-102.

Dovidio, J. F., Gaertner, S. L., Niemann, Y. F., \& Snider, K. (2001). Racial, ethnic and cultural differences in responding to distinctiveness and discrimination on campus: Stigma and common group identity. Journal of Social Issues, 57(1), 167-188.

Dunbar-Ortiz, R. (2015). An Indigenous people's history of the United States. Beacon Press.

Epps, E. G. (1973). Race relations: Current perspectives. Winthrop Publishers.

Esposito, L., \& Murphy, J. W. (2000). Another step in the study of race relations. Sociological Quarterly, 41(2), 171-187.

Farmworker Justice. (2017). Farmworker justice: Empowering farmworkers to improve their living and working conditions since 1981. Retrieved from www.farmworkerjustice.org.

Feagin, J. R., \& Feagin, C. B. (1994). Theoretical perspectives in race and ethnic relations. In F. L. Pincus \& H. J. Ehrlich (Eds.), Contending views on prejudice, discrimination, and ethnoviolence (pp. 29-47). Westview Press.

Feagin, J. R., \& Feagin, C. B. (2011). Racial and ethnic relations, census update (9th ed.). Pearson.

Fiske, S. T. (2013). A millennial challenge: Extremism in uncertain times. Journal of Social Issues, 69(3), 605-613.

Fredrickson, G. (2002). Racism: A short history. Princeton University Press.

Glazer, N., \& Moynihan, D. P. (1963). Beyond the melting pot: The Negroes, Puerto Ricans, Jews, Italians and Irish of New York City. MIT Press.

Gonyea, D. (2017). Majority of white Americans say they believe whites face discrimination. NPR. www .npr.org/2017/10/24/559604836/majority-of-white-americans-think-theyre-discriminated-against

Goodman, D. (2011). Promoting diversity and social justice: Educating people from privileged groups (2nd ed.). Routledge.

Gordon, M. M. (1964). Assimilation in American life: The role of race, religion, and national origins. Oxford University Press.

Grosfoguel, R. (2011). Decolonizing post-colonial studies and paradigms of political-economy: Transmodernity, decolonial thinking, and global coloniality. Transmodernity: Journal of Peripheral Cultural Production of the Luso-Hispanic World, 1(1).

Guglielmo, J., \& Salerno, S. (Eds.). (2003). Are Italians White? How race is made in America. Routledge.

Hernstein, R., \& Murray, C. (1994). The bell curve: Intelligence and class structure in American life. Free Press.

Houston, S. (2001). Beyond social constructionism: Critical realism and social work. The British Journal of Social Work, 31(6), 845-861.

Ignatiev, N. (1995). How the Irish became White. Routledge.

Jansson, B. (2015). The reluctant welfare state: Engaging history to advance social work practice in contemporary society (8th ed.). Cengage.

Kiernan, B. (2009). Blood and soil: A world history of genocide from Sparta to Darfur. Yale University Press. 
Kinloch, G. C. (1974). The dynamics of race relations: A sociological analysis. McGraw Hill.

Kinloch, G. C. (1979). The sociology of minority group relations. Prentice-Hall.

Kolbert, E. (2018). There's no scientific basis for race - it's a made up label. National Geographic, https:// www.nationalgeographic.co.uk/people-and-culture/2018/04/theres-no-scientific-basis-race-its -made-label

Kovel, J. (1970/2001). White racism: A psychohistory. In E. Cashmore \& J. Jennings (Eds.), Racism: Essential readings (pp. 136-140). Sage.

Leonardo, Z., \& Porter, R. (2010). Pedagogy of fear: Toward a Fanonian theory of 'safety' in race dialogue. Race, Ethnicity and Education, 13, 139-157.

Leong, N. (2012). Racial capitalism. Harvard Law Review, 126, 2151.

Lopez, I. F. H. (1994). The social construction of race: Some observations on illusion, fabrication, and choice. Harvard Civil Rights-Civil Liberties Law Review, 29(1), 1-62.

Lopez, I. F. H. (1996). White by law: The legal construction of race. New York University Press.

McDonagh, E. C., \& Richards, E. S. (1953). Ethnic relations in the United States. Appleton-Century-Crofts.

McDowell, T., \& Jens, L. (2004). Talking about race using critical race theory: Recent trends. Journal of Marital and Family Therapy, 30(1), 81-94.

Mclaughlin, J., \& Hennebry, J. (2013). Pathways to precarity: Structural vulnerabilities and lived consequences in the everyday lives of migrant farmworkers in Canada. In L. Goldring \& P. Landolt (Eds.), Producing and negotiating non-citizenship: Precarious legal status in Canada (pp. 1-15). University of Toronto Press.

Memmi, A. (2000). Racism. University of Minnesota Press.

Miller, J., \& Schamess, G. (2000). The discourse of denigration and the creation of other. Journal of Sociology and Social Welfare, 27(3), 39-62.

Mills, C. W. (1997). The racial contract. Cornell.

Montagu, A. (1965/2001). Man's most dangerous myth: The fallacy of race. In E. Cashmore \& J. Jennings (Eds.), Racism: Essential readings (pp. 98-110). Sage.

Murphy, J., Samples, J., Morales, M., \& Shadbeh, N. (2015). "They talk like that, but we keep working": Sexual harassment and sexual assault experience among Mexican Indigenous farmworker woman in Oregon. Journal of Immigrant and Minority Health, 193(1), 118-125.

Myrdal, G. (1962). An American dilemma. In M. W. Hughey (Ed.), New Tribalisms: The resurgence of race and ethnicity (pp. 61-72). Palgrave Macmillan.

Nelson, L. (2008). Racialized landscapes: Whiteness and the struggle over farmworker housing in Woodburn, Oregon. Cultural Geographies, 15(1), 41-62.

Omi, M., \& Winant, H. (2014). Racial formation in the United States: From the 1960s to the 1990s (3rd ed.). Routledge.

Painter, N. I. (2010). The history of white people.

Power, S. (2002). A problem from hell: America in the age of genocide. Basic Books.

Quandt, S. A., Wiggins, M. F., Chen, H., Bischoff, W. E., \& Arcury, T. A. (2013). Heat index inmigrant farmworker housing: Implications for rest and recovery from work-related heat stress. American Journal of Public Health, 103(8), 24-26.

Quijano, A. (2007). Coloniality and modernity/rationality. Cultural Studies, 21(2-3), 168-178.

Ramos, A. K. (2017). A human rights-based approach to farmworker health: an overarching framework to address the social determinants of health. Journal of Agromedicine. 1059924X.2017.1384419.

Reid, J. (2015). Fracture: Barack Obama, the Clintons, and the racial divide. HarperCollins.

Resendez, A. (2017). The other slavery: The uncovered story of Indian enslavement in America. Mariner Books.

Robinson, E., Nguyen, H. T., Isom, S., Quandt, S. A., Grzywacz, J. G., Chen, H., \& Arcury, T. A. (2011). Wages, wage violations, and pesticide safety experienced by migrant farmworkers in North Carolina. New Solutions: A Journal of Environmental and Occupational Health Policy, 21(2), 251-268.

Rollock, D., \& Gordon, E. W. (2000). Racism and mental health into the 21st century: Perspectives and parameters. American Journal of Orthopsychiatry, 70(1), 5-13.

Sacks, K. B. (1996). How did Jews become White folks? In S. Gregory \& R. Sanjek (Eds.), Race (pp. 78-102). Rutgers. 


\section{Racism in the United States}

Schiller, B. R. (1998). The economics of poverty and discrimination (7th ed.). Prentice Hall.

Schwartz, S. J., Unger, J. B., Zamboanga, B. L., \& Szapocznik, J. (2010). Rethinking the concept of acculturation. American Psychologist, 65(4), 237-251.

Segal, B. S. (Ed.). (1966). Racial and ethnic relations: Selected readings. Thomas W. Crowell.

Simpson, G. E., \& Yinger, J. M. (1953). Racial and cultural minorities: An analysis of prejudice and discrimination. Harper \& Brothers.

Skillings, J. H., \& Dobbins, J. E. (1991). Racism as a disease: Etiology and treatment implications. Journal of Counseling and Development, 70(1), 206-212.

Solorzano, D., Ceja, M., \& Yosso, T. (2000). Critical race theory, racial microaggressions, and campus racial climate: The experiences of African American college students. Journal of Negro Education, 69(1/2), $60-73$.

Steinberg, S. (2001). The ethnic myth: Race, ethnicity and class in America (3rd ed.). Beacon Press.

Takaki, R. (1993). A different mirror: A history of multi-cultural America. Little, Brown.

Taylor, R. (1997). The changing meaning of race in the social sciences: Implications for social work practice. Smith College Studies in Social Work, 67(3), 277-298.

Telega, S. W., \& Maloney, T. R. (2010). Legislative Actions on Overtime Pay and Collective Bargaining and their Implications for Farm Employers in New York State, 2009-2010. Charles H. Dyson School of Applied Economics and Management College of Agriculture and Life Sciences Cornell University.

Tilly, C. (1998). Durable inequality. University of California Press.

Vander Zanden, J. W. (1963). American minority relations: The sociology of race and ethnic groups. Ronald Press.

Walsh, J. (2013). What's the matter with White people? Finding our way in the next America. Touchstone.

Waugh, I. M. (2010). Examining the sexual harassment experiences of Mexican immigrant farmworking women. Violence Against Women, 16(3), 237-261.

Wellman, D. (2000). From evil to illness: Medicalizing racism. American Journal of Orthopsychiatry, 70(1), $28-32$.

Wilson, W. J. (1973). Power, racism and privilege: Race relations in theoretical and sociohistorical perspectives (pp. 47-67). Free Press.

Wilson, W. J. (1987). The truly disadvantaged: The inner-city, the underclass and public policy. University of Chicago.

Wilson, W. J. (2011). When work disappears: The world of the new urban poor. Vintage.

Winant, H. (1997). Racial dualism at century's end. In W. Lubiano (Ed.), The house that race built: Black Americans, U.S. terrain (pp. 87-115). Pantheon.

Yancy, G., \& Mills, C. (2014). Lost in Rawlsland. The New York Times. http://opinionator.blogs.nytimes. com/2014/11/16/lost-in-rawlsland/?emc=etal\&_r=0 